Terbit online pada laman : http://teknosi.fti.unand.ac.id/

\title{
Dampak Dan Faktor Kesuksesan Penerapan Enterprise Resource Planning Terhadap Kinerja Organisasi: Sistematic Literature Review
}

\author{
Muhammad Nur Hendra Alvianto ${ }^{a *}$, Nabiel Putra Adam ${ }^{a}$, Ilham Akbar Sodik $^{a}$, Eko Sediyono $^{b}$, Aris Puji \\ Widodo $^{a}$ \\ ${ }^{a}$ Magister Sistem Informasi, Sekolah Pascasarjana, Universitas Diponegoro, Jl. Imam Bardjo SH No. 5, Semarang, 50241, Indonesia \\ ${ }^{b}$ Magister Sistem Informasi, Universitas Kristen Satya Wacana, Salatiga, Jl. Diponegoro 52-60, Salatiga, 50711, Indonesia
}

\section{INFORMASI ARTIKEL}

Sejarah Artikel:

Diterima Redaksi: 08 November 2021

Revisi Akhir: 20 Januari 2022

Diterbitkan Online: 21 Januari 2022

\section{KATA KUNCI}

Enterprise Resource Planning,

Impact ERP Implementation,

Effect ERP Implementation,

Success Factor ERP Implementation

KORESPONDENSI

E-mail: nurhendraalvi1103@students.undip.ac.id*

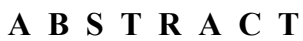

Perkembangan teknologi informasi yang semakin pesat saat ini mendorong organisasi atau perusahaan untuk melakukan investasi dan penerapan teknologi informasi. Salah satu investasi atau penerapan pada bidang teknologi informasi yaitu penerapan Enterprise Resource Planning $(E R P)$. penerapan ERP dilakukan untuk membantu organisasi atau perusahaan dalam mencapai tujuan bisnisnya. Namun, penerapan ERP pada organisasi atau perusahaan tidaklah mudah dan memiliki dampak yang harus dihadapi oleh organisasi apabila mengalami kegagalan dalam implementasi ERP. pada penelitian ini dilakukan untuk mengetahui faktor - faktor yang menentukan kesuksesan atau kegagalan dalam menerapkan ERP pada organisasi atau perusahaan. Selain itu, pada penelitian ini juga dilakukan untuk mengetahui dampak yang terjadi dari kegagalan atau keberhasilan dalam menerapkan ERP pada organisasi atau perusahaan. Penelitian ini dilakukan dengan mengkaji literatur yang terdapat pada penelitian mengenai penerapan ERP pada organisasi atau perusahaan. Berdasarkan kajian literatur yang dilakukan pada penelitian ini mendapatkan faktor - faktor yang banyak diperhatikan oleh peneliti sebelumnya dalam menerapkan ERP yaitu user training, top management support dan vendor support yang akan mempengaruhi keberhasilan atau kegagalan dalam menerapkan ERP. keberhasilan dan kegagalan pada penerapan ERP juga berdampak pada kinerja organisasi. Keberhasilan penerapan ERP berdampak pada kinerja organisasi yang meningkat dari sebelum adanya penerapan ERP. Peningkatan kinerja tidak hanya pada organisasi, melainkan berdampak juga pada kinerja karyawan yang bekerja. Selain dampak dari keberhasilan penerapan ERP, Penerapan ERP juga dapat mengalami kegagalan. Kegagalan pada penerapan ERP yaitu organisasi atau perusahaan dapat mengalami kerugian pada investasi di bidang teknologi informasi.
\end{abstract}

\section{PENDAHULUAN}

Perkembangan teknologi informasi yang terjadi saat ini memiliki pengaruh terhadap banyak hal baik kehidupan masyarakat maupun organisasi. Organisasi atau perusahaan menggunakan atau menerapkan teknologi informasi untuk mendukung kinerja pengambilan keputusan yang lebih efektif dan efisien dalam mencapai tujuan dari proses bisnisnya. Salah satu penerapan teknologi informasi untuk mendukung kinerja organisasi yaitu Enterprise Resource Planning (ERP). ERP merupakan suatu sistem terintegrasi dengan tujuan untuk menyederhanakan proses bisnis yang dimiliki oleh organisasi agar lebih efektif dan efisien dengan dukungan dari penerapan teknologi informasi agar dapat menghasilkan informasi untuk mendukung kinerja dari sebuah organisasi [1]. Fungsi dari ERP yaitu melakukan integrasi antara proses-proses bisnis yang terdapat di organisasi atau dapat disebut juga sebagai integrasi antara proses yang dimulainya produk baru berupa bahan mentah sampai dengan produk tersebut menjadi sebuah produk yang siap dipasarkan ke pasaran [2].

Organisasi dapat merasakan banyaknya manfaat dari penerapan ERP, salah satunya yaitu organisasi dapat menjadi lebih efektif dalam menjalankan proses bisnisnya dengan berdampak pada 
produktifitas dari kinerja yang lebih baik dari organisasi tersebut. Selain itu organisasi dapat memangkas biaya untuk penyediaan sumber daya manusia dengan memanfaatkan ERP yaitu dengan melakukan integrasi antar divisi untuk dapat dengan mudah mendapatkan informasi yang tersedia di setiap divisi tersebut [3].

Banyaknya manfaat yang dapat dirasakan oleh organisasi memiliki beberapa dampak yang dapat dirasakan oleh organisasi, dampak yang dirasakan yaitu dampak negatif maupun dampak positif yang dapat dirasakan oleh organsiasi. Terdapat beberapa penelitian yang membahas mengenai dampak penerapan ERP pada organisasi. Menurut penelitian yang dilakukan oleh [4] organisasi mendapatkan banyak manfaat dari implementasi ERP yang dilakukannya. Namun, banyaknya manfaat tersebut juga sebanding dengan banyaknya tantangan yang harus dihadapi oleh organisasi dalam mengimplementasikan ERP yaitu antara lain organisasi memiliki keterbatasan kemampuan dalam pengembangan dan teknis implementasi ERP, terjadi perubahan struktur organisasi pada organisasi setelah ERP diimplementasikan, selain terjadi perubahan struktur organisasi juga berdampak pada perubahan tanggung jawab pada karyawan atau staf yang menjalankan organisasi. Kemudian pada penelitian yang dilakukan oleh [5] terdapat beberapa pengaruh dari tidak berpengaruhnya penerapan dari ERP pada kinerja organisasi yaitu terdapat pengaruh dari sektor industri yang bergerak secara khusus pada penerapan ERP, hal tersebut berdampak pada tidak adanya peningkatan secara signifikat mengenai efisiensi dari kinerja organisasi.

Kemudian terdapat penelitian yang dilakukan oleh [6] yang membahas mengenai dampak dari penerapan ERP berdasarkan perseptif pengguna dalam meningkatkan kinerjanya. Pada penelitian ini terdapat perbandingan dari kinerja pengguna antara sebelum dan setelah penerapan ERP. Saat sebelum penerapan ERP pengguna atau staf dari Universitas Jember merasa dalam pemantauan pekerjaannya tidak dapat terpantau pekerjaan yang telah selesai ataupun belum selesai, selain itu mereka merasa standarisasi yang diberikan tidak dapat diukur dengan baik. Sedangkan setelah penerapan dari ERP mereka merasa terdapat dampak positif dari penerapannya yaitu antara lain pekerjaan yang telah dikerjakan dapat dengan mudah dilakukan pemantauan agar mengetahui pekerjaan yang telah selesai ataupun belum, selain itu pihak Universitas Jember dapat memantau standarisasi dari pekerjaan yang dilakukan oleh tenaga kependidikannya.

Implementasi ERP memiliki hubungan dengan strategis bisnis, kemampuan dari organisasi dan kinerja organisasi. Hubungan yang terjadi antara implementasi ERP dengan strategis bisnis memiliki dampak yang positif bagi organisasi. Dampak yang positif tersebut juga berdampak pada kinerja dari oragnisasi yang lebih efisien dan efektif dalam mencapai tujuan bisnis organisasi dan pengambilan keputusan organisasi [7].

Penerapan ERP memiliki dampak yang positif pada pekerja yang menggunakan ERP di perusahaan yang bergerak pada bidang industri kulit. Variable complexity, compatibility, facilitating condition, perceive usefulness, perceived of use dan individual performance merupakan variable-variable yang berpengaruh dengan memberikan dapak positif bagi pengguna selama menggunakan ERP. Penerapan ERP pada perusahaan yang bergerak industri kulit ini memiliki salah satu kunci dari suksesnya penerapan ERP yaitu komitmen dari manajemen dan pelatihan penggunaan sistem ERP [8].

Penerapan ERP pada organisasi dapat diibaratkan sebagai dua bilah mata pisau karna didalam penerapan ERP dapat dikatakan berhasil dan bisa juga dikatakan tidak berhasil. Penelitian yang dilakukan oleh [9] dengan melakukan penelitian unutk membuktikan bahwa penerapan ERP memiliki dampak pada produktivitas bisnis dari organisasi. Hasil dari penelitian tersebut membuktikan bahwa penerapan ERP memiliki hubungan dengan meningkatnya produktivitas bisnis dari organisasi, peningkatan produktivitas merupakan sebuah manfaat yang dapat dirasakan oleh organisasi dalam menerapkan ERP untuk mendukung kegiatan bisnis dari organisasi tersebut.

Pada penelitian ini dilakukan penelitian dengan melakukan peninjauan ulang dari penelitian yang telah dilakukan sebelumnya yaitu pada penelitian ini membahas dampak dari penerapan ERP terhadap kinerja dari organisasi. Peninjauan ulang dari penelitian yang dilakukan dengan melakukan pencarian penelitian-penelitian yang telah dilakukan dengan berbagai penerapan ERP pada organisasi dari berbagai bidang organisasi dengan tujuan untuk mengetahui dampak dari penerapan ERP akan kinerja organisasi tersebut.

\section{METODE}

Metode penelitian yang digunakan dengan menggunakan metodologi penelitian tinjauan pustaka sistematis atau sistematic literature review (SLR). SLR merupakan suatu penelitian dengan melakukan pemrosesan untuk mengindentifikasi, menilai dan menafsirkan suatu fakta dan buti yang didapatkan dari penelitian yang telah dilakukan sebelumnya [10]. Terdapat tahapan yang dilakukan untuk penelitian dengan SLR.

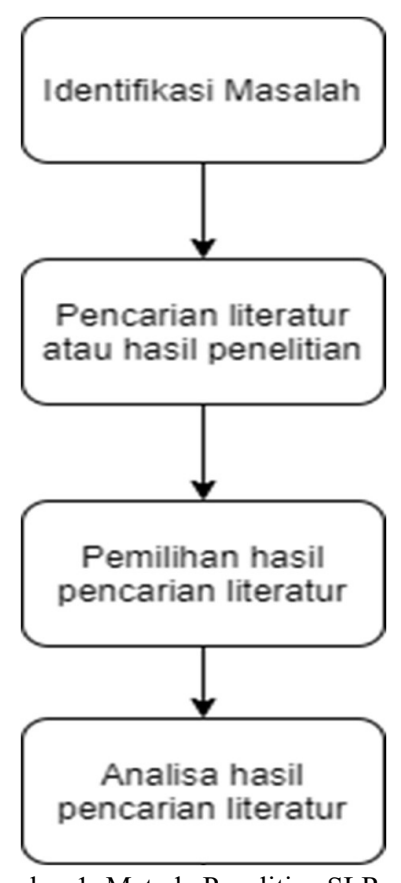

Gambar 1. Metode Penelitian SLR 


\subsection{Identifikasi Masalah}

Pada tahap ini yaitu dengan menentukan tujuan dan hasil yang diinginkan dari penelitian yang dilakukan dengan menggunakan sistematic literature review. Penelitian ini dilakukan dengan tujuan untuk mengetahui dampak yang terjadi dari penerapan ERP pada kinerja organisasi. Untuk mencapai tujuan tersebut, maka dapat dirumuskan masalah sebagai berikut:

a. Q1: Bidang organisasi apa saja yang menerapkan ERP untuk mendukung kinerja organisasinya ?

b. Q2: Bagaimana faktor penentu keberhasilan atau kegagalan dari penerapan ERP?

c. Q3: Bagaimana dampak penerapan ERP pada kinerja organisasi?

\subsection{Pencarian Literature atau Hasil Penelitian}

Pada tahap ini yaitu dengan melakukan pencarian literature dari berbagai sumber baik jurnal nasional, konferensi internasional maupun jurnal internasional. Pencarian literature ini dengan menggunakan beberapa kata kunci yaitu penerapan ERP, dampak penerapan ERP, kinerja organisasi, the effect of ERP Implementation, impact of ERP Implementation, dan critical success factor of ERP implementation. Literatur yang diperoleh dari hasil pencarian yaitu sebagai berikut :

Tabel 1. Pencarian Literature

\begin{tabular}{lccc}
\hline \multicolumn{1}{c}{ Kata Kunci } & $\begin{array}{c}\text { Science } \\
\text { Direct }\end{array}$ & IEEE & $\begin{array}{c}\text { Springer } \\
\text { Link }\end{array}$ \\
\hline $\begin{array}{l}\text { the effect of ERP } \\
\text { Implementation }\end{array}$ & 6,863 & 24 & 5,638 \\
\hline $\begin{array}{l}\text { impact of ERP } \\
\text { Implementation }\end{array}$ & 6,052 & 33 & 6,056 \\
\hline $\begin{array}{l}\text { critical success factor of } \\
\text { ERP implementation }\end{array}$ & 1,408 & 30 & 2,941 \\
\hline
\end{tabular}

\subsection{Pemilihan Hasil Pencarian Literatur}

Pada ini yaitu dengan memilah hasil dari pencarian literatur yang didapatkan sebelumnya dengan menyaring jurnal atau hasil konferensi yang telah dilakukan sebelumnya. Pemilihan ini dilakukan berdasarkan kriteria yang telah ditentukan sebelumnya yaitu sebagai berikut:

a. Paper atau prosiding konferensi yang diterbitkan dengan rentang waktu 2015-2021.

b. Paper atau prosiding konferensi didapatkan dari sumber jurnal atau konferensi yang terpercaya

c. Paper atau prosiding konferensi yang didapatkan dari hasil pencarian harus dapat menjawab permasalahan berdasarkan rumusan masalah yang dibahas pada penelitian ini.

d. Paper atau prosiding konferensi yang digunakan diutamakan dengan tippe penelitian studi kasus dengan menggunakan survey sebagai metodologi untuk pengambilan data.

Berdasarkan kriteria tersebut maka didapatkan hasil yaitu dengan jumlah paper sebanyak 20 paper.

\subsection{Analisa Hasil Pencarian Literatur}

Tahap ini yaitu melakukan analisis dari hasil pencarian literatur yang telah dipilih berdasarkan kriteria yang telah ditentukan sebelumnya. Analisis dilakukan dengan merangkum hasil dari pencarian literatur yang memiliki hubungan dengan pengaruh kinerja organisasi pada penerapan ERP. Analisis dilakukan dengan mengelompokkan jenis dan isi dari paper berdasarkan kata kunci yang telah ditentukan sebelumnya yaitu the effect of ERP Implementation, impact of ERP Implementation.

Hasil dari analisa pencarian literatur juga dapat menentukan faktor keberhasilan atau kegagalan apa saja yang berpengaruh kinerja organisasi pada penerapan ERP. Faktor okeberhasilan atau kegagalan dapat dimanfaatkan oleh organisasi dalam mencegah kegagalan dan resiko dari kegagalan pada penerapan ERP yang diterapkan oleh organisasi.

\section{HASIL DAN PEMBAHASAN}

Pada tahapan pencarian yang dilakukan, maka diperoleh hasil pencarian literatur yang terdiri dari paper atau prosiding konferensi. Hasil yang didapaptkan sebelumnya terdiri dari beberapa bidang perusahaan yang menerapkan ERP untuk mendukung kegiatan organisasi dari masing - masing oraganisasi tersebut. Berikut merupakan bidang perusahaan yang menerapkan ERP untuk mendukung kegiatan organisasi, yaitu sebagai berikut

Tabel 2. Persebaran Bidang Organisasi

\begin{tabular}{cc}
\hline Bidang Organisasi & Literatur \\
\hline Manufaktur \& Konstruksi & {$[11][12][13]$} \\
\hline SMEs & {$[14][15][16][17]$} \\
\hline Pendidikan & {$[18][19][20]$} \\
\hline Financial & {$[21]$} \\
\hline Distributor & {$[22][23]$} \\
\hline Plam Oil/Oil Company & {$[24][25]$} \\
\hline Automotive & {$[26][27]$} \\
\hline Power Industry & {$[28]$} \\
\hline Public Sector & {$[29][30]$} \\
\hline
\end{tabular}

Berdasarkan Tabel 2 dapat dipetakan persebaran bidang organisasi yang menerapkan ERP untuk mendukung kegiatan bisnis di organisasinya. Berdasarkan pemetaan tersebut maka penggunaan ERP pada organisasi banyak digunakan pada sektor SMEs atau bisnis menengah dan kecil. Banyak faktor yang mempengaruhi keberhasilan dari penerapan ERP pada organisasi seperti top management support, change managemen dan masih banyak lagi. Berdasarkan pemetaan dari berbagai bidang organisasi tersebut maka dapat ditentukan faktor-faktor yang terpenting atau yang paling banyak berpengaruh akan keberhasilkan dari implementasi dari ERP yaitu dapat digambarkan sebagai berikut: 


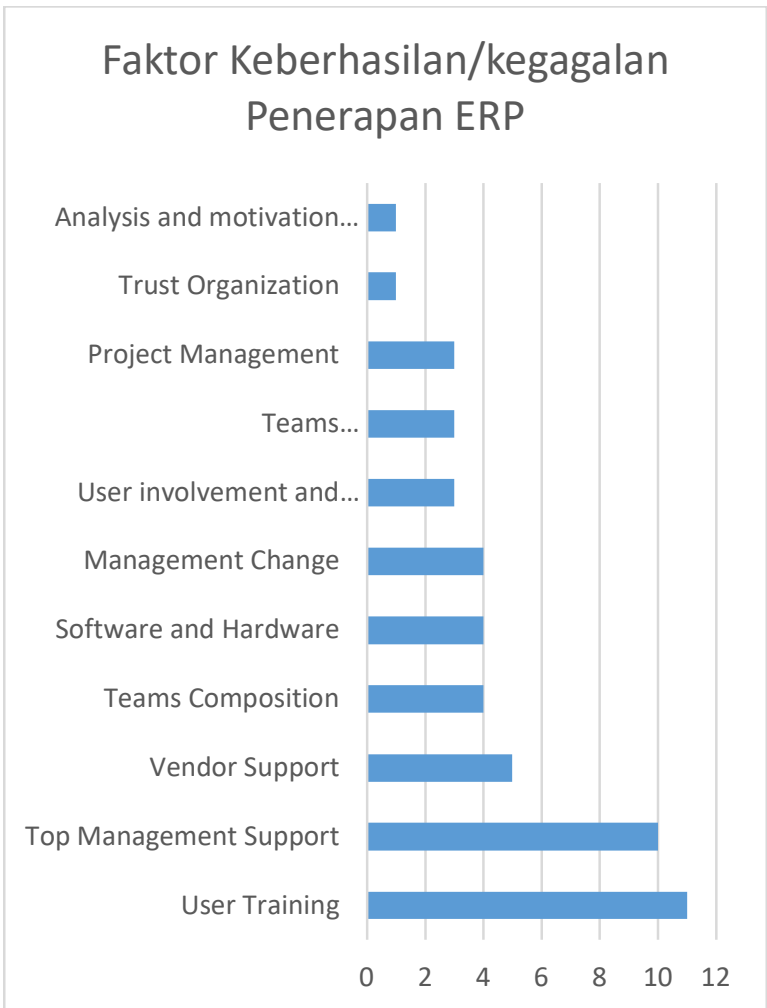

Gambar 2. Faktor Keberhasilan atau Kegagalan Penerapan ERP

Pada gambar 2 merupakan beberapa faktor yang mendukung keberhasilan dari penerapan ERP. Terdapat 3 faktor penentu yang paling sering disebutkan dari keberhasilan atau kegagalan dari sebuah penerapan ERP berdasarkan literatur-literatur yang didapatkan dari berbagai bidang organisasi yaitu User Training, Top Management Support, and Vendor Support.

\subsection{User Training}

Faktor pertama dalam menentukan keberhasilan atau kegagalan dari sebuah penerapan ERP pada organisasi yaitu User training. Pengguna ERP sendiri bisa terdiri dari beberapa bagian di organisasi seperti level operasional, middle management hingga top management. Menurut penelitian yang dilakukan oleh [31] user training merupakan salah satu faktor penting yang menentukan keberhasilan dari penerapan ERP di suatu organisasi. Pelatihan ERP untuk pengguna melibatkan keseluruhan fitur yang terdapat pada ERP, pelatihan ini didasarkan pada prinsip transfer pengetahuan yang terdapat pada ERP. user training memiliki tujuan untuk dapat membantu user dalam menggunakan dan beradaptasi akan sistem baru berupa ERP dan perubahan yang terjadi pada proses bisnis di organisasi untuk dapat menghasilkan dampak yang positif dalam menerapkan ERP pada organisasi.

Penerapan ERP pada organisasi merupakan hal yang cukup krusial, hal tersebut dikarenakan ERP merupakan sistem yang kompleks untuk digunakan oleh organisasi dan membutuhkan pelatihan untuk menggunakan sistem tersebut. Pelatihan yang kurang memadai dalam proses pelatihan bagi pengguna merupakan salah satu faktor yang mempengaruhi keberhasilan dari penerapan ERP pada organisasi. User merupakan sebuah key yang harus memiliki berbagai informasi mengenai penggunaan
ERP dalam mendukung kinerja mereka pada sebuah organisasi [32].

Menurut penelitian yang dilakukan oleh [33] user training terbagi menjadi dua jenis yaitu classroom training dan shop-floor training. Classroom training terdiri dari berbagai sesi dan berbagai jenis pelatihan dengan tujuan untuk dapat menggunakan ERP yang lebih baik. Kemudian pada shop-floor training dilakukan untuk memperkenalkan ERP kepada pengguna dengan melakukan pelatihan pada fungsional yang terdapat pada ERP.

Calon user ERP harus melakukan pelatihan terlebih dahulu untuk mengetahui penggunaan dari sistem ERP dan dapat lebih mengenal mengenai perubahan proses bisnis yang terjadi pada organisasi yang dapat berdampak pada pekerjaan yang dikerjakan oleh user. Terdapat tiga buah aspek yang dapat digunakan dalam melakukan pelatihan bagi pengguna yaitu logika dan konsep ERP, fitur perangkat lunak pada sistem ERP dan hands-on training [34]. Pelatihan dilakukan untuk pengguna agar dapat lebih mengenal perubahan proses bisnis yang terjadi di organisasi atas implementasi ERP yang dilakukan oleh organisasi. Selain itu, pelatihan juga bertujuan agar pengguna dapat lebih mengenal perubahan yang terjadi pada pekerjaan yang biasa dilakukan oleh mereka ke pekerjaan dengan memanfaatkan implementasi sistem ERP [35].

Menurut penelitian yang dilakukan oleh [36] pelatihan juga dikatakan penting bagi organisasi dalam menentukan keberhasilan dari penerapan ERP, hal tersebut bertujuan untuk membantu change management dalam menerapan ERP dan proses perubahan proses bisnis yang terjadi pada organisasi. Pelatihan bagi pengguna sistem ERP juga merupakan salah satu pencegahan atau manajemen resiko akan ketidakmampuan pengguna dalam menggunakan ERP untuk mendukung kinerja organisasi. Ketidakmampuan pengguna akan berdampak pada sebuah kegagalan pada penerapan ERP pada organisasi [36].

Pelatihan yang ditujukan bagi pengguna merupakan salah satu faktor penting untuk menentukan keberhasilan dari penerapan ERP pada organisasi. Organisasi yang akan dan baru menerapkan ERP harus melihat faktor utama yaitu user training agar penerapan ERP dapat berhasil dan memberikan dampak baik bagi kinerja organisasi. Selain itu, pelatihan bagi pengguna memiliki dampak yang baik bagi pengguna itu sendiri yaitu pengguna dapat lebih mengetahui perubahan yang terjadi pada proses bisnis perusahaan dan pekerjaan yang mereka kerjaan. Kemudian adanya pelatihan bagi pengguna juga dapat membantu change management dalam memantau perubahan yang terjadi antara sebelum dan sesudah penerapan ERP. Selain itu, pelatihan juga dapat meminimalisir terjadinya penolakan oleh pengguna atau karyawan atau anggota pada perusahaan atau organisasi yang akan menerapkan dan baru menerapkan organisasi dikarenakan mereka merasa terancam akan tergantikannya posisi pekerjaan mereka dengan sebuah sistem baru yang akan atau baru saja diimplementasikan di organisasi atau di perusahaan. 


\subsection{Top Management Support}

Faktor kedua dalam menentukan keberhasilan atau kegagalan dari sebuah penerapan ERP pada organisasi yaitu Top Management Support. Dukungan yang diberikan oleh menejemen level atas yaitu dengan menjamin akan ketersediaan sumber daya dan wewenang yang diperlukan dalam mendukung keberhasilan manajemen proyek impelemtasi ERP [32].

Menurut penelitian yang dilakukan oleh [37] top management support merupakan salah satu faktor penentu dari keberhasilan penerapan ERP pada organisasi atau perusahaan. Pada faktor ini dipengaruhi oleh cara kepemimpinan yang dilakukan oleh manajer tingkat atas dalam mengatasi permasalahan atau pengambilan sauatu kebiajakan pada jalannya organisasi. Terdapat dua cara kepemimpinan yang memiliki pengaruh pada penerapan ERP secara efektif yaitu transformational leadership dan transactional leadership.

Penelitian yang dilakukan oleh [38] yaitu berpendapat bahwa peran dan dukungan dari top management merupakan suatu faktor dari keberhasilan penerapan teknologi informasi. Gaya kepemimpinan yang dimiliki oleh top management salah satu pengaruh dari keberhasilan penerapan ERP. faktor gaya kepemimpinan yang dimiliki oleh top management yaitu dapat dilihat mulai dari perencanaan awal yaitu perencanaan penerapan dari ERP. selain itu gaya kepemimpinan yang dimiliki oleh top management menjadi penentu dalam menentukan suasana pada perusahaan untuk dapat selalu belajar dan berproses dalam mencapai tujuan perusahaan dengan adanya penerapan ERP.

Peran dan dukungan yang diberikan oleh top management yaitu dengan keterlibatan dan partisipasi dari top management pada organisasi atau perusahaan dalam melakukan pengawasan dan pemantauan pada proyek implementasi ERP. Peran dan dukungan yang diberpkan top management yaitu dengan mendukung proses implementasi ERP dan memantau segala proses yang dilakukan oleh tim proyek agar sesuai dengan tujuan dan harapan yang diinginkan oleh top management [39].

Dukungan, komitmen dan partisipasi dari top management merupakan faktor terpenting dalam menentukan keberhasilan atau kegagalan dari sebuah penerapan ERP pada organisasi atau perusahaan. Dukungan yang diberikan oleh top management akan berpengaruh pada jalannya proses dari implementasi ERP. faktor dukungan akan mempengaruhi jalannya penerapan ERP. seperti buruknya gaya kepemimpinan atau kurangnya dukungan akan mempengaruhi proses implementasi ERP dan berdampak pada kegagalan dari penerapan ERP [40].

Salah satu contoh kasus yang terdapat pada penelitian yang dilakukan oleh [40] yaitu terdapat dua dukungan dari top management pada proyek penerapan ERP. yang menjadi pembeda dari keduanya yaitu dukungan yang diberikan pada jalannya proyek penerapan ERP. kasus yang pertama top management hanya memberikan komitmen pada awal pelaksanaan proyek selebihnya mengalami kehilangan focus dan berdampak pada proyek pengembangan ERP. kemudian pada kasus yang kedua yaitu top management memberikan komitmen dari awal hingga proyek penerapan ERP berakhir dan secara rutin memantau perkembangan dari proyek tersebut. Berdasarkan dua

176 Muhammad Nur Hendra Alvianto kasus tersebut, dukungan dan keterlibatan dari top management akan memberikan pengaruh yang signifikan akan keberhasilan atau kegagalan dari penerapan ERP.

Keterlibatan top management dalam memberikan dukungan dan peran pada pelaksanaan proyek ERP akan memberikan dampak yang signifikan akan keberhasilan atau kegagalan dari penerapan ERP. gaya kepemimpinan, pengambilan keputusan, komitmen yang diberikan dan keterlibatan secara langsung dalam melakukan pemantauan, pengarahan dan pengambilan keputusan selama proyek implementasi ERP akan berpengaruh pada organisasi tersebut.

\subsection{Vendor Support}

Faktor ketiga yang menentukan keberhasilan atau kegagalan dalam penerapan ERP berdasarkan hasil dari penelitian yang telah dilakukan yaitu vendor support. Dukungan yang diberikan dapat berupa penyediaan software ataupun hardware maupun pengembangan ERP untuk organisasi atau perusahaan. Menurut penelitian yang dilakukan oleh [41] menyatakan peranan vendor dalam memberikan dukukan pada penerapan ERP di organisasi merupakan faktor penting dalam menentukan keberhasilan dari suatu penerapan ERP pada organisasi.

Organisasi juga harus dapat memilih vendor yang tepat dalam mendukung implementasi ERP. pemilihan vendor yang tepat untuk mendukung implementasi ERP dapat menentukan keberhasilan atau kegagalan dari penerapan ERP. Penentuan vendor dapat dilakukan oleh organisasi atau perusahaan dengan melihat beberapa faktor salah satunya tingkat pengalaman dan keberhasilan dari kasus - kasus sebelumnya yang dipegang oleh vendor tersebut dalam menerapkan ERP. Disisi lain dukungan vendor juga dapat menentukan keberhasilan atau kegagalan dari penerapan ERP. Vendor harus ikut terjun dalam proyek implementasi ERP dengan memastikan keseluruhan proyek tersebut dapat tepat waktu sesuai dengan analisa pada awal proyek. Selain itu hubungan dengan organisasi juga harus terjaga untuk dapat membangun sebuah kepercayaan dari oragnisasi yang memanfaatkan jasa dari vendor yang digunakan [40].

Menurut penelitian yang dilakukan oleh [42] menyatakan kagagalan dalam penerapan ERP dapat terjadi pada dukungan yang diberikan oleh vendor. Kegagalan penerapan ERP yang terjadi dikarenakan dukungan vendor yaitu terdapat beberapa faktor yang berpengaruh antara lain gagalnya vendor dalam beradaptasi dengan budaya yang dimiliki oleh organisasi, kegagalan dalam merumuskan ulang proses bisnis yang terdapat pada organisasi, kurangnya informasi yang terdapat pada organisasi, ketidakmampuan dalam beradaptasi akan perubahan bisnis dan ekonomi yang terjadi, kegagalan pengendalian biaya yang digunakan dalam proyek implementasi ERP dan mengalami kegagalan teknis pada saat penerapan ERP berlangsung. 
Dukungan vendor dapat menentukan keberhasilan atau kegagalan dari penerapan ERP, terdapat langkah - langkah yang dapat dilakukan oleh organisasasi dalam menentukan vendor yang terbaik untuk memberikan dukungan pada penerapan ERP [43], yaitu sebagai berikut :

A. Pemilihan vendor dan pengumpulan berbagai informasi terkait produk ERP dan keberhasilan proyek yang dikerjakan oleh vendor.

B. Melakukan identifikasi kebutuhan yang dibutuhkan oleh organisasi pada penerapan ERP.

C. Membuat sebuah tim yang bertanggung jawab untuk melaksanakan proyek implementasi ERP

D. Memilah dengan cara mengeliminasi vendor-vendor yang ada dan menentukan dua pilihan terbaik dari vendor-vendor yang didapatkan.

E. Lakukan perbandingan yang diberikan antar vendor untuk mendapatkan harga yang terbaik dan lakukan negosiasi harga untuk proses implementasi ERP

Peran dan dukungan yang diberikan oleh vendor ditentukan berdasarkan hasil dari penentuan organisasi dalam menentukan vendor yang akan digunakan untuk memberikan dukungan pada penerapan ERP. Pemilihan yang dilakukan oleh organisasi akan menentukan keberhasilan dari penerapan ERP, hal tersebut dikarenakan peran dan dukungan yang diberikan vendor juga ditentukan oleh pengalaman yang dimiliki vendor dalam menentukan keberhasilan atau kegagalan dari penerapan ERP. Selain itu, faktor kepercayaan juga berpengaruh pada pemilihan vendor dan penggunaan vendor yang memberikan dukungan untuk melakukan dukungan pada penerapan ERP di organisasi atau perusahaan. Kepercayaan yang diberikan antara vendor dan organisasi dapat menentukan keberlangsungan dari jalannya proyek implementasi ERP. Ketika salah satu atau keduanya memiliki ketidakpercayaan maka akan berdampak pada gagalnya proyek atau kegagalan pada penerapan ERP.

\subsection{Dampak Penerapan ERP}

Dampak dari penerapan ERP pada organisasi akan berpengaruh pada keberlangsungan kinerja organisasi. Dampak yang terjadi dari keberhasilan atau kegagalan dapat dirasakan langsung oleh organisasi. Masing - masing dari dampak yang dirasakan memberikan efek yang berbeda bagi organisasi terutama pada kinerja organisasi.

Menurut penelitian yang dilakukan oleh [23] keberhasilan penerapan ERP dapat mempengaruhi kinerja dari perusahaan. Keberhasilan dari penerapan ERP mempengaruhi kinerja pegawai pada perusahaan yang menggunakan ERP untuk mendukung pekerjaannya. Kualitas informasi yang dihasilkan dari penerapan ERP berpengaruh pada peningkatan kinerja pada karyawan yang menggunakan sistem secara langsung. Kepuasan karyawan dalam menggunakan sistem ERP berdampak pada kualitas yang diberikan dari hasil penerapan ERP.

Salah satu contoh kasus yang terdapat pada penelitian yang dilakukan oleh [30] penerapan ERP pada bagian keuangan dapat berdampak baik pada kinerja akuntan dalam mendukung pekerjaannya. Peningkatan kinerja yang dirasakan oleh akuntan keuangan yaitu dengan bertambahnya akses data yang didapatkan pada perusahaan tempat akuntan tersebut bekerja. Selain itu, akuntan tersebut dapat dengan mudah memanfaatkan media penyimpanan yang lebih besar pada sistem ERP. Penerapan ERP yang menggabungkan keseluruhan sistem berdampak pada penggambungan akses data pada seluruh bagian pada perusahaan, hal tersebut dapat membantu akuntan dalam membuat laporan keuangan atau perencanaan keuangan pada perusahaan. Tidak hanya pemanfaatan data yang menjadi lebih efektif dan efisien dalam mengaksesnya, melainkan dalam proses pengolahan untuk menjadi sebuah laporan atau perencanaan keuangan dapat didukung oleh sistem ERP untuk memudahkan kinerja dari akuntan dan menambah kinerja organisasi yang menjadi lebih cepat dalam menentukan tujuan dari organisasi atau perusahaan.

Keberhasilan dalam proses penerapan ERP akan berdampak pada peningkatan kinerja organisasi atau perusahaan. Peningkatan kinerja tidak hanya secara keseluruhan pada organisasi atau perusahaan melainkan peningkatan terjadi dari kinerja karyawan, kinerja pada bagian didalam organisasi atau perusahaan juga. Peningkatan kinerja pada organisasi atau perusahaan juga berdampak pada efisiensi dan efektifitas kinerja dan proses bisnis pada organisasi atau perusahaan dengan mengalami peningkatan pencapaian pada tujuan yang telah ditentukan sebelumnya.

Dampak penerapan ERP tidak selalu berhasil dalam meningkatkan kinerja pada organisasi atau perusahaan. Melainkan kegagalan pada penerapan ERP di organisasi atau perusahaan. Kegagalan dari penerapan ERP pada organisasi atau perusahaan dapat terjadi karna beberapa faktor atau kesalahan dari organisasi atau perusahaan dalam menentukan kebijakan atau penerapan sistem ERP. faktor - faktor yang menjadi penyebab kegagalan penerapan ERP [44] yaitu kesalahan dalam metode pelatihan untuk pengguna ERP, perencanaan dalam implementasi ERP yang salah dan dukungan manajemen yang kurang, kegagalan perubahan tujuan pada proses bisnis organisasi atau perusahaan, dan terjadinya penolakan pada sistem yang baru diimplementasikan.

Kegagalan dalam proses penerapan ERP akan berdampak pada kinerja organisasi dan kegagalan investasi teknologi informasi yang dilakukan oleh organisasi atau perusahaan. Investasi pada bidang teknologi informasi yang dilakukan oleh organisasi atau perusahaan berupa penerapan ERP tidaklah mudah. Kegagalan penerapan ERP yang terjadi dikarenakan beberapa faktor akan berdampak pada kerugian yang harus dihadapi oleh organisasi atau perusahaan. Selain itu, perusahaan melakukan perencanaan dari awal apabila penerapan ERP yang mengalami kegagalan sebelumnya tidak dapat diperbaiki dan berdampak pada bertambahnya biaya dan waktu implementasi ERP.

\section{KESIMPULAN}

Penerapan ERP pada organisasi dapat mendukung kinerja organisasi dari berbagai bidang organisasi tersebut. Peningkatan kinerja pada organisasi pada berbagai bidang tersebut didapatkan dari faktor-faktor pendukung keberhasilan pada penerapan ERP. faktor - faktor yang paling banyak disebutkan berdasarkan literatur yang didapatkan dalam menentukan keberhasilan atau kegagalan dari penerapan ERP yaitu user training, top management support dan vendor support. Namun, tidak menutup 
kemungkinan terdapat faktor - faktor lain yang menentukan keberhasilan atau kegagalan dalam menerapkan ERP.

Keberhasilan atau kegagalan dalam menerapkan ERP pada organisasi akan berdampak pada kinerja organisasi. Kegagalan pada penerapan ERP berdampak pada kerugian perusahaan dalam melakukan investasi pada bidang teknologi informasi. Selain itu, kegagalan dalam penerapan ERP juga berdampak pada waktu dan biaya dalam melakukan perencanaan kembali dalam melakukan implementasi ERP pada organisasi. Dampak yang terjadi pada keberhasilan penerapan ERP yaitu organisasi atau perusahaan dapat merasakan peningkatan kinerja dalam mencapai tujuan bisnis pada organisasi atau perusahaan. Peningkatan kinerja tidak hanya dirasakan oleh organisasi atau perusahaan, melainkan juga dirasakan oleh karyawan yang bekerja dengan mendapat kemudahan dalam mendukung pekerjaan yang diberikan oleh organisasi atau perusahaan

\section{DAFTAR PUSTAKA}

[1] P. Hofmann, "ERP is dead, long live ERP," IEEE Internet Comput., vol. 12, no. 4, pp. 84-88, 2008, doi: 10.1109/MIC.2008.78.

[2] T. Q. Ferbia, "Analisis Penggunaan Sistem ERP untuk Transformasi Proses Bisnis Studi Kasus: Supermarket Bangunan dan Furniture," JUTIM (Jurnal Tek. Inform. Musirawas), vol. 3, no. 2, pp. 74-82, 2018, doi: 10.32767/jutim.v3i2.313.

[3] A. N. Izzati and N. F. Najwa, "Pengaruh Stakeholder Perspective Dalam Penerapan ERP: A Sistematic Literature Review," J. Teknol. Inf. dan Ilmu Komput., vol. 5, no. 1, p. 41, 2018, doi: 10.25126/jtiik.201851540.

[4] N. Nawaz and K. Channakeshavalu, "The Impact of Enterprise Resource Planning (ERP) Sistems Implementation on Business Performance," SSRN Electron. J., no. June, pp. 30-47, 2020, doi: 10.2139/ssrn.3525298.

[5] H. Zhang and H. Zheng, "An Empirical Study on the Impact of ERP Implementation on the Performance of Listed Companies," J. Phys. Conf. Ser., vol. 1213, no. 5, 2019, doi: 10.1088/1742-6596/1213/5/052103.

[6] A. Andrianto, "Impact of Enterprise Resource Planning (ERP) implementation on user performance: Studies at University of Jember," J. Phys. Conf. Ser., vol. 1211, no. 1, 2018, doi: 10.1088/1742-6596/1211/1/012040.

[7] M. Nawawi, "Dampak Implementasi Erp Terhadap Kapabilitas Organisasi Dan Kinerja Perusahaan," J. Ris. Akunt. Terpadu, vol. 11, no. 2, pp. 238-253, 2018, doi: 10.35448/jrat.v11i2.4263.

[8] L. Liesnaningsih, F. Fandhilah, and D. Kasoni, "Analisis Dampak Implementasi Sistem Enterprise Recource Planning Terhadap Kinerja Pengguna pada PT.Baiksan Indonesia," J. Inov. Inform., vol. 5, no. 1, pp. 55-63, 2020, doi: 10.51170/jii.v5i1.34.

[9] Rudi, D. Arisandy, and Salsalina, "Pengaruh penerapan Enterprise Resource Planning ( ERP ) terhadap peningkatan produktivitas bisnis perusahaan ( Studi kasus : PT . XYZ )," Jikom J. Inform. dan Komput., vol. 7, no. 2, pp. 57-65, 2017.

[10] M. H. Diponegoro, S. S. Kusumawardani, and I. Hidayah, "Tinjauan Pustaka Sistematis: Implementasi Metode Deep Learning pada Prediksi Kinerja Murid ( Implementation of Deep Learning Methods in Predicting Student Performance: A Sistematic Literature Review )," J. Nas. Tek. Elektro dan Tek. Inf., vol. 10, no. 2, pp. 131-138, 2021, [Online]. Available: https://journal.ugm.ac.id/v3/JNTETI/article/view/1417.

178 Muhammad Nur Hendra Alvianto
[11] M. M. Nkasu, "Investigation of the Effects of Critical Success Faktors on Enterprise Resource Planning (ERP) Sistems Implementation in the United Arab Emirates," Smart Intell. Comput. Appl., pp. 611-623, 2019.

[12] T. Saleh and M. Thoumy, "The impact of ERP sistems on organizational performance: In Lebanese wholesale engineering companies," 2018 7th Int. Conf. Ind. Technol. Manag. ICITM 2018, vol. 2018-Janua, pp. 198-204, 2018, doi: 10.1109/ICITM.2018.8333946.

[13] S. Aboabdo, A. Aldhoiena, and H. Al-Amrib, "Implementing Enterprise Resource Planning ERP Sistem in a Large Construction Company in KSA," Procedia Comput. Sci., vol. 164, pp. 463-470, 2019, doi: 10.1016/j.procs.2019.12.207.

[14] M. Nikitovic and V. Strahonja, "The analysis of CSFs in stages of ERP implementation - Case study in small and medium-sized (SME) companies in Croatia," 2016 39th Int. Conv. Inf. Commun. Technol. Electron. Microelectron. MIPRO 2016 - Proc., pp. 1494-1499, 2016, doi: 10.1109/MIPRO.2016.7522375.

[15] P. D. Deshmukh, G. T. Thampi, and V. R. Kalamkar, "Investigation of quality benefits of ERP implementation in Indian SMEs," Procedia Comput. Sci., vol. 49, no. 1, pp. 220-228, 2015, doi: 10.1016/i.procs.2015.04.247.

[16] M. Ağaoğlu, E. S. Yurtkoru, and A. K. Ekmekçi, "The Effect of ERP Implementation CSFs on Business Performance: An Empirical Study on Users' Perception," Procedia - Soc. Behav. Sci., vol. 210, pp. 35-42, 2015, doi: 10.1016/j.sbspro.2015.11.326.

[17] M. I. Nofal and Z. M. Yusof, "Critical success faktors enhancing enterprise resource planning sistems implementation in Jordanian SMEs," Proc. - 5th Int. Conf. Electr. Eng. Informatics Bridg. Knowl. between Acad. Ind. Community, ICEEI 2015, pp. 98-103, 2015, doi: 10.1109/ICEEI.2015.7352477.

[18] H. A. Eka Widjaja et al., "Analysis Measurement of Implementation Enterprise Resource Planning on Human Resource Management in University XYZ," 6th Int. Conf. Comput. Eng. Des. ICCED 2020, 2020, doi: 10.1109/ICCED51276.2020.9415764.

[19] E. Abu-Shehab, R. Abu-Shehab, and M. Khairallah, "Critical Success Faktors for ERP Implementation: The Case of Jordan," Int. Arab J. e-Technology, vol. 4, no. 1, pp. 1-7, 2015.

[20] C. E. T. Wanko, J. R. K. Kamdjoug, and S. F. Wamba, "Study of a Successful ERP Implementation Using an Extended Information Sistems Success Model in Cameroon Universities: Case of CUCA Chris," World Conf. Inf. Syst. Technol., vol. 19, pp. 460-472, 2019, doi: 10.1007/978-3-030-16181-1.

[21] R. A. Wijaya, P. Widyaningrum, B. Prasetyo, and R. Satria, "Analyzing of implementation enterprise budgeting sistem using SAP BPC: Case study on a financial government institution," 2018 Int. Conf. Adv. Comput. Sci. Inf. Syst. ICACSIS 2018, no. 2007, pp. 475480, 2019, doi: 10.1109/ICACSIS.2018.8618253.

[22] A. D. Putri, M. Lubis, and A. H. Azizah, "Analysis of critical success faktors (CSF) in enterprise resource planning (ERP) implementation using extended technology acceptance model (TAM) at trading and distribution company," 2020 4th Int. Conf. Electr. Telecommun. Comput. Eng. ELTICOM 2020 - Proc., pp. 129-135, 2020, doi: 10.1109/ELTICOM50775.2020.9230527.

[23] J. S. Suroso, R. B. Budhijana, and R. I. Delfiani, "The Effect of Successful Enterprise Resource Planning (ERP) Sistems on Employee Performance," 2018 Int. Conf. Orange Technol. ICOT 2018, pp. 1-6, 2018, doi: $\underline{10.1109 / \text { ICOT.2018.8705850. }}$

https://doi.org/10.25077/TEKNOSI.v7i3.2021.172-180 
[24] J. Kembaren and D. Budiastuti, "Role of Mobility Strategy in moderating the effect of ERP performance to operational performance: (Study in Indonesian palm oil plantation industries)," Proc. 2016 Int. Conf. Inf. Manag. Technol. ICIMTech 2016, no. November, pp. 200-204, 2017, doi: 10.1109/ICIMTech.2016.7930329.

[25] A. A. L. Jafari and S. S. K. Nair, "ERP Implementation in the Oil and Gas Sektor: A Case Study in Sultanate of Oman," 2018 7th Int. Conf. Reliab. Infocom Technol. Optim. Trends Futur. Dir. ICRITO 2018, vol. 7, pp. 848854, 2018, doi: 10.1109/ICRITO.2018.8748779.

[26] S. Aini, M. Lubis, R. W. Witjaksono, and A. Hanifatul Azizah, "Analysis of Critical Success Faktors on ERP Implementation in PT. Toyota Astra Motor Using Extended Information Sistem Success Model," Mecn. 2020 - Int. Conf. Mech. Electron. Comput. Ind. Technol., pp. 370-375, 2020, doi: 10.1109/MECnIT48290.2020.9166653.

[27] S. J. Prasetyo, M. Lubis, R. W. Witjaksono, and A. H. Azizah, "Critical Failure Faktors in Enterprise Resource Planning (ERP) Implementation: Case Study of PT.Toyota Astra Motor Indonesia," Proc. 2019 4th Int. Conf. Informatics Comput. ICIC 2019, 2019, doi: 10.1109/ICIC47613.2019.8985720.

[28] N. Hasanah, W. W. Winarno, and A. Amborowati, "Analisis Keberhasilan Implementasi Enterprise Resource Planning di PT Indonesia Power," J. PPKM III, vol. 10, no. 1, pp. 249-257, 2016.

[29] D. Fernandez, Z. Zainol, and H. Ahmad, "The impacts of ERP sistems on public sektor organizations," Procedia Comput. Sci., vol. 111, pp. 31-36, 2017, doi: 10.1016/j.procs.2017.06.006.

[30] D. Appelbaum, A. Kogan, M. Vasarhelyi, and Z. Yan, "Impact of business analytics and enterprise sistems on managerial accounting," Int. J. Account. Inf. Syst., vol. 25, no. March, pp. 29-44, 2017, doi: 10.1016/j.accinf.2017.03.003.

[31] S. Dezdar, "ERP Implementation Projects in Asian Countries," Int. J. Inf. Technol. Proj. Manag., vol. 8, no. 3, pp. 52-68, 2017, doi: 10.4018/ijitpm.2017070104.

[32] M. Taghipour, M. Shabrang, H. H. Machiani, and N. Shamami, "Assessment and Analysis of Risk Associated with the Implementation of Enterprise Resource Planning (ERP) Project Using FMEA Technique The Impact of ICT on Knowledge Sharing Obstacles in Knowledge Management Process (Including CaseStudy) View project Asse," Int. Technol. Sci., vol. 3, no. 2, pp. 2617-4596, 2020, doi: $10.31058 /$ j.mana.2020.32002.

[33] N. Obwegeser, P. Danielsen, K. S. Hansen, M. A. Helt, and L. H. Nielsen, "Selection and training of super-users for ERP implementation projects," J. Inf. Technol. Case Appl. Res., vol. 21, no. 2, pp. 74-89, 2019, doi: $\underline{10.1080 / 15228053.2019 .1631606 .}$.

[34] L. Tata, "Critical success faktors in ERP implementation in Indian manufacturing enterprises: an exploratory analysis Shree Ranjan * and Vijay Kumar Jha Pralay Pal," Int. J. Bus. Inf. Syst., vol. 28, no. 4, pp. 404-424, 2018.

[35] M. O. Malik and N. Khan, "Analysis of ERP implementation to develop a strategy for its success in developing countries," Prod. Plan. Control, vol. 0, no. 0 , pp. 1-16, 2020, doi: $10.1080 / 09537287.2020 .1784481$.

[36] A. Jiwasiddi and B. Mondong, "Analysing ERP implementation critical success faktors for SME: A study of sap one implementation in Jakarta," Pertanika J. Soc. Sci. Humanit., vol. 26, no. T, pp. 139-146, 2018.

[37] Z. Shao, Y. Feng, and Q. Hu, "Effectiveness of top management support in enterprise sistems success: A contingency perspective of fit between leadership style and sistem life-cycle," Eur. J. Inf. Syst., vol. 25, no. 2, pp. 131-153, 2016, doi: 10.1057/ejis.2015.6.

[38] J. C. Lee, Y. C. Shiue, and C. Y. Chen, "Examining the impacts of organizational culture and top management support of knowledge sharing on the success of software process improvement," Comput. Human Behav., vol. 54, pp. 462-474, 2016, doi: 10.1016/i.chb.2015.08.030.

[39] S. Chaveesuk and S. Hongsuwan, "A Structural Equation Model of ERP Implementation Success in Thailand," Rev. Integr. Bus. Econ. Res., vol. 6, no. 3, pp. 194-204, 2017.

[40] N. S. A. Suhaimi, A. Nawawi, and A. S. A. P. Salin, "Determinants and problems of successful ERP implementations - Malaysian experience," Int. J. Adv. Oper. Manag., vol. 9, no. 3, pp. 207-223, 2017, doi: 10.1504/IJAOM.2017.088252.

[41] P. Garg and R. Khurana, "Applying structural equation model to study the critical risks in ERP implementation in Indian retail," Benchmarking, vol. 24, no. 1, pp. 143162, 2017, doi: 10.1108/BIJ-12-2015-0122.

[42] M. Ali and L. Miller, "ERP sistem implementation in large enterprises - a sistematic literature review," $J$. Enterp. Inf. Manag., vol. 30, no. 4, pp. 666-692, 2017, doi: 10.1108/JEIM-07-2014-0071.

[43] L. F. Motiwalla and J. Thompson, Enterprise Sistem For Management. Pearson Education, Inc., Upper Saddle River, New Jersey, 2009.

[44] A. Noudoostbeni, N. M. Yasin, and H. S. Jenatabadi, "To investigate the sucess and failure faktors of ERP implementation within malaysian small and medium enterprises," Proc. - 2009 Int. Conf. Inf. Manag. Eng. ICIME 2009, pp. 157-160, 2009, doi: https://doi.org/10.1109/ICIME.2009.66.

\section{BIODATA PENULIS}

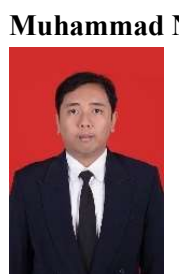

Nur Hendra Alvianto

Muhammad Nur Hendra Alvianto, lahir di Cirebon, Jawa Barat pada tanggal 11 Maret 1999. Menyelesaikan studi program sarjana Sistem Informasi di Universitas Pembangunan Nasional "Veteran" Yogyakarta dengan bidang Pengembangan dan Pengintegrasian Sistem Informasi. Saat ini, penulis sedang melanjutkan studi di Program Magister Sistem Informasi, Universitas Diponegoro, Semarang

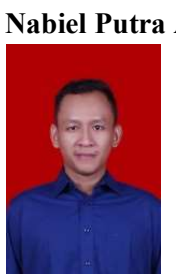

\section{dam}

Nabiel Putra Adam lahir di Semarang, pada tanggal 22 Oktober 1992. Menyelesaikan studi program sarjana Teknik Industri di Universitas Diponegoro Semarang dengan bidang Supply Chain. Saat ini sedang melanjutkan studi di Sistem Informasi Sekolah Pasca Sarjana Universitas Diponegoro Semarang.

\section{Ilham Akbar Sodik}

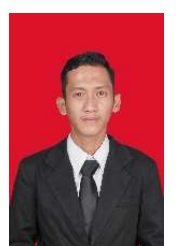

Ilham Akbar Sodik lahir di Karanganyar pada 10 Juli 1998. Menyelesaikan pendidikan Program Sarjana Informatika (S1) pada Fakultas Komunikasi dan Informatika di Universitas Muhammadiyah Surakarta. Saat ini penulis sedang melanjutkan pendidikan di Program 
Magister Sistem Informasi (S2) pada Sekolah Pascasarjana di Universitas Diponegoro Semarang.

\section{Eko Sediyono}

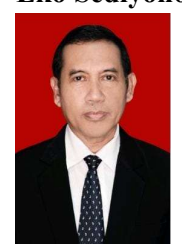

Eko Sediyono memperoleh gelar sarjana statistika dari IPB (Institut Pertanian Bogor) di Bogor pada tahun 1985. Magister di bidang Ilmu Komputer diperoleh di Universitas Indonesia, Jakarta, pada tahun 1993. Gelar Doktor di bidang Ilmu Komputer diperoleh di Universitas Indonesia pada tahun 2006, dan Guru besar di bidang Ilmu Komputer dikukuhkan pada tahun 2008. Penulis adalah dosen tetap di Fakultas Teknologi Informasi, Universitas Kristen Satya Wacana sejak tahun 1987 sampai sekarang. . Selain itu penulis juga aktif mengajar di Magister Sistem Informsi UKSW, Manajemen Pendidikan UKSW, Doktor Manajemen, dan Doktor Studi Pembangunan, Magister Sistem Informasi, Magister Ilmu Kesehatan Masyarakat, dan Doktor Sistem Informasi Universitas Diponegoro.

\section{Aris Puji Widodo}

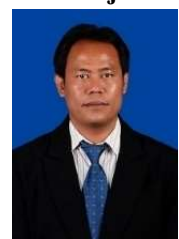

Aris Puji Widodo lahir di Grobogan pada tanggal 01 April 1974. Menyelesaikan studi program doktoral Ilmu Komputer di Universitas Gadjah Mada Yogyakarta dengan bidang Interoperabilitas e-Government. Saat ini sebagai pengajar di Departemen Informatika Universitas Diponegoro Semarang. 